\title{
Economic and Adoption Impacts of Modern Irrigation Technologies at River Nile State of Sudan: A Case Study Alfalfa Fodder-legume Crop
}

\author{
Elgilany A. Ahmed* and Hamid Hussein M. Faki \\ Agricultural Research Corporation, Agricultural Economics and Policy Research Center, Sudan \\ *Correspondence: elgilanya@yahoo.com
}

Received on: 22/9/2020

Accepted on: 20/12/2020

\begin{abstract}
Advanced technologies have the potential to raise water use efficiency and water productivity per unit, labour efficiency can also be improved. The research reported in this paper seeks to evaluate the economic impacts of modern irrigation technologies' adoption and its application to the alfalfa winter-season fodder crops grown in the River Nile State of North Sudan (RNS). Integrated analytical techniques were applied to attain the aims of the study. A descriptive statistical analysis for crop water applied and crop water requirements for the main crops in area of the study. GAMS, CropWat 4 and SPSS were used to evaluate modern and conventional farming systems and their irrigation water performance. Different production activities, concerned with winter-season crops were identified, with emphasis on alfalfa legume crop to illustrate different irrigation technology levels in the RNS. The model constraints were also examined including irrigation water, land and labour. Model scenarios were developed to investigate possible production options and to examine the different agricultural resource levels and policy implications that might affect the adoption of these new technologies. The model findings revealed that conventional irrigation systems were not economically feasible options compared to modern ones. This reflects actual farmers' behaviour, particularly for irrigation water, and indicates that water is the main resource constraint. The study findings investigate water resources policies in developing countries that may cause great distortions resulting in negative effects on resources use. This study concluded that investment and application of advanced irrigation technologies in different agricultural sectors are needed.
\end{abstract}

KEYWORDS: modern irrigation technology, alfalfa legumes, adoption,

\section{INTRODUCTION}

In River Nile State of North Sudan (RNS), a combination of winter field crops is considered as crucial to be identified and evaluated. The winter season is ranked asthe first and principal season for State tenants in terms of agricultural production, while the summer and autumn "demira" seasons are ranked next after it due to some climatic factors that give advantages for winter-season crops compared to that of the other seasons' crops. Alfalfa winter-season crop is a perennial fodder legume and is often used in crop rotations of the farming systems throughout the north and middle regions of Sudan to supply fodder and provide nitrogen for subsequence cereal field crops. It has a significant contribution to farm sustainability, household food security, and income. Among the dominant crop combinations in the north of the country, alfalfa crop is usually grown for three to five production years and harvested mechanically or manually according to the farm size. This research has been implemented in River Nile State (RNS)of north Sudan. The State is considered as one of the most promising States in the country, it enjoys relatively cooler weather during the winter season "Shetwi" and endowed with fertile alluvial soils. Also, it has comparative advantages compared to other parts of Sudan in producing relatively high-value field crops and perennials. These crops are dominant in the region such as citruses, mangos, dates, wheat, faba beans, certain spices and medical plants.

The River Nile is known as one of the longest rivers in the world, it is considered as the main source of irrigation water for the agricultural cultivated areas, particularly for the mentioned winter-seasoncrops production, while the summer "Saifi" and autumn "demira" season crops are ranked after them due to some environmental advantages as well as some economical aspects.The State is endowed with numerous types of irrigation schemes with different approaches such as the public irrigated schemes, foreign' investment schemes, agricultural companies,private and cooperative schemes with different farming systems, and production relationships. 


\section{Elgilany A. Ahmed and Hamid Hussein M. Faki., 2020}

These schemes are regarded as the main potential ones for developing agriculture in general and specifically to produce winter-season crops due to their high acreage share, available capital, machineries, and a high number of farmers. The research selected El-Zeidab public irrigation scheme as one of the study cases since it represents conventional irrigation systems in the State. It is the oldest and the biggest belonging to the State Ministry of Agriculture. The total area of the scheme is about 22,000 feddans $(1$ Feddan $=0.42$ Hectare $)$. Beside ElZeidab's scheme, the study chose Elkafaa-Al-Rajhi's scheme to represent modern irrigation systems in the Berber locality of RNS. The location of Elkafaa-AlRajhi's scheme is considered an appropriate site to apply modern farming systems such as advanced irrigation technologies (i.e. pivot sprinkler irrigation system) and where there is potential to improve agricultural production. The scheme is considered as one of the recent foreign investment schemes in River Nile State and is located at about $350 \mathrm{~km}$ north of Khartoum. It was established by Al-Rajhi International for Investment of Saudi Arabia and the Ministry of Agricultural and Forestry of Sudan as an initiative from the King Abdullah of Saudi Arabia. It was constructed between 2007 and 2012. The total area of the scheme was originally about 100,000 feddan devoted to grain and fodder production. The scheme is applying international experiences of agricultural development and advanced irrigation technologies for agricultural production. The research observed some critical constraints regarding determination of crop combination in the area of study. These constraints contribute mainly to low overall crop yields. Causes of fluctuation of winter crop yields include are; inadequate practices of technical packages used by farmers, misuse of agricultural resources, stress caused and inflicted by changing environmental and climatic conditions, especially temperature. Furthermore, widespread diseases, insects, pests, weeds and power failure that are accompanied by lack and high cost of fuel and spare parts to operate the pumps are faced agricultural production in the State.

Numerous research papers (Ismaiel Ahmed (2019) and Faki et al (2004)) mention that the high cost of production coupled with low levels of crop yields and unstable source of power has made it difficult for tenants to realize the full potential of the State. In addition, development is constrained by serious limitation on the two basic resources, namely land and water. Regarding irrigation water in the State, many hindrances contributed to inefficient irrigation water use and which affect crop production in the irrigation schemes in RNSsuch as the inadequate supply of irrigation inputs in the proper time and at right prices. Generally, improvement of the farming system in the State, considering climatic change and food security and economic requirements of the local populations, is regarded as a great challenge for researchers, policy makers, scientists, agricultural administrators in public and private sectors, related organizations, and investors. The author applies metrics in terms of resource-use advantages relative to economic returns and crop yields.

\section{The Main Research Objective}

This research seeks to evaluate the economic impacts of modern irrigation technologies' adoption and its application to the alfalfa (Medicago sativa L.) winter-season fodder crops grown in the River Nile State of North Sudan (RNS). Within the host of challenges confronting the State, the study also determines the promising crop combinations that include alfalfa fodder-legume.

\section{MATEREALS AND METHODES}

This research was carried out in the River Nile State. The climatic conditions of the State allow the production of a wide range of perennial and seasonal crops.

\subsection{Area of the Study}

The farming system in RNS includes mainly four types economic approaches in the agricultural namely, private or individual, cooperative, public pump and foreign investment. Tropical and subtropical fruits grown include dates, citruses, mango, banana and guava. Soils are alluvial, which are generally fertile, are made up of loamy and silt deposits, generally well-drained non-saline and nonsodic (Ahmed, 2004). Many studies (Ahmed (2009) and Abdallah (1995)) mentioned that the RNS has been assumed to have a comparative advantage in cash and food crops production namely, legumes, vegetables, cereals and spices beside perennial crops including alfalfa, citruses, mango, guava and palm dates. This assumption is based on the State's favorable climatic conditions, vast endowments such as land, permanent sources of irrigation, and accumulated experiences of skilled farmers. Besides the River Nile, Atbara River and underground water are other important direct resources of irrigation water in the agricultural sector of RNS. Although the RNS is characterized by past comparative advantages, the last decade has witnessed frequent debates about the 


\section{Scientific Journal of Agricultural Sciences 2 (2): 240-255, 2020}

deterioration of agricultural production, which has manifested itself in numerous indicators such as low crop productivity, high cost of production, inadequate credit facilities, and markets and prices instability. This situation raises the conviction that the stability of the irrigation sub-sector forms a major driver for achieving food security, poverty alleviation, and improving the livelihood of the farmers of the scheme. This present study has been based on two case studies namely, El-Zeidab public irrigated scheme, and AlRajhi-Kafaa foreign investment irrigated scheme. AlRajhi-Kafaa irrigated scheme is characterized as a modern scheme applying fully-mechanized systems. Its production system is based mainly on annual field crops such as grains, pulses, fodder, and other agricultural activities, while the farming system of ElZeidab scheme is distinguished mainly as a semimechanized system. The prevalent crop combination in the RNS often includes field crops, perennials, and animal production activities.

\subsection{Simple size and data collection techniques}

This research depended mainly on primary data from areas of the study, besides secondary data from relevant official sources. The method selected for primary data collection was direct personal interviewing of respondents while following a structured questionnaire. The process of data collection was achieved by the researcher as well as trained numerators.

The primary and secondary data were collected for the season 2015/2016 to compiles information concerning the operation of the schemes under study.

\subsection{Sample size}

In order to secure reasonable precision, stratified random sampling techniques were applied based on sample size proportional to the relative sizes of the targeted groups in the public irrigated scheme, while taking into consideration limitations in survey budgets, available time, and available facilities. The total number of farmers in Elzeidab scheme at the time of the survey was estimated at 3000 . Elzeidab scheme consists four divisions namely, Northern, Medium, Southern, and Elahali (MAS, 2016). The sample size for this study is 70 farmers were selected randomly from Elzeidab scheme, which formed about $2.3 \%$ of the total farmers in the scheme. Further, a comprehensive secondary data set was obtained from Al-Rajhi-Kafaa irrigated scheme. A few hindrances were faced in the two case studies; firstly: in ElZeidab public scheme inadequate infrastructure made travel and field work within the study area rather difficult. The tenants of El-Zeidab were often skeptical about the research work. Some of the tenants were uncertain about, and had mistrust in the aims of research work, thinking that it aims to raise taxes so their response was sometimes very poor. Some others reported that numerous research work had been done in their tenancies without tangible returns in the scheme. Secondly: Elkafaa scheme is regarded as a new scheme in the area of study when compared to the public ones. Therefore, the accessibility for the required information and other technical data is not reported properly.

\subsection{Analytical techniques}

Numerous techniques were applied to achieve the goals of the study. A descriptive statistical analysis was used. In this part of the analysis, graphical, frequency distribution, and statistical analysis were applied. The computation of the crop water requirements (CWR) of any crop requires estimation of its crop coefficient values. The Food and Agriculture Organization's (FAO) Penman-Monteith (PM) method was recently developed to assess ETo values from a hypothetical reference crop that was more consistent with the actual CWR and has been recommended by the FAO as the standard method for CWR calculation designed in the software program CROPWAT4 (Ahmed, 2009). For the on-farm wateruse efficiency (FWUE), the research has adopted ICARDA's (2001) concept to evaluate the efficiency of on-farm water use. The concept of ICARDA concerning FWUE has been developed to address farm levels where complexity exists. The definition of FWUE by ICARDA is a ratio of required irrigation water to produce a specific output level to the actual amount of water applied by farmers. Linear programming (LP) analytical technique also was employed using General Algebraic Modeling System (GAMS) (Ahmed, 2009). GAMS is described as a flexible program and it is easy to use for such a study. The model objective aims to attain net return maximization and/or irrigation water optimization (minimum water use). The mathematical LP model formulation includes numerous components namely the objective function, the constraints (i.e. land, irrigation water, capital, labor), and activities that used the field crop.

\subsection{The objective function (objfn)}

The model is to determine the course of action to achieve the optimum allocation of irrigation water in the northern region and will appear later as Max $\pi$. 


\section{Elgilany A. Ahmed and Hamid Hussein M. Faki., 2020}

\subsection{The constraints}

The above-mentioned objectives are subjected to sets of constraints that are to be integrated within the LP model.

a) Farmland constraint: The sum of areas allocated to farm crops in a particular period or season must be equal to or less than the total available farm land for the targeted season.

b) Irrigation water constraint: The operation of pumping irrigation water from the River Nile or underground water is expensive. Furthermore, most of the farmers and schemes' administrators are unaware of the available amount of irrigation water as well as the crops water requirements per watering or/and per season, it is essential for the irrigation water constraint to be assessed seasonally. Thus, allocation of irrigation water must be equal to or less than the total available irrigation water per season.

c) Labour constraint: The seasonal labour requirement for the cultivated area should equal or be less than the total available labour in that particular season.

d) Capital constraints: The total cost of production should equal or be less than the total available capital for producing the targeted field crops.

e) Non-negativity: The algorithm must allocate positive amounts of resources use (i.e. land, water) to maximize the objective function $(X j \geq 0$, all $j=1$ to $n)$.

The model also applied some scenarios to maximize net return on investment (ROI) subject toa set of physical constraints on-farm land, irrigation water, labor and capital. Therefore, the model was specified with maximization of gross profit margins (GPM), and the GPM is known as the percentage of revenue that is actual profit before adjusting for operating costs, such as marketing, overhead, and salaries. The two factors that determine gross profit margin are revenue and cost of goods sold (COGS). COGS is what it directly costs the company to make a product, while the gross marketing margins (GMM) is defined as the percentage of revenue that is actual profit before adjusting for operating costs, such as marketing, overhead, and salaries. The two factors that determine gross profit margin are revenue and cost of goods sold (COGS). COGS is what it directly costs the company to make a product, thus the objective function will be as follows:

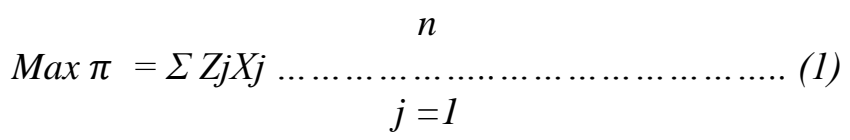

Such that:

$$
\Sigma \alpha i j X j \leq \text { bi, all } 1 \text { to } m=\ldots \ldots \ldots \ldots \ldots \ldots \ldots \ldots \ldots
$$

And:

$\mathrm{Xj} \geq 0$, all $\mathrm{j}=1$ to $n$

Where:

$\pi=$ is objective function value per year,

$\mathrm{Xj}=$ Level of the $\mathrm{j}^{\text {th }}$ the farm activity, such as the acreage of wheat grown. Let $n$ denote the number of possible activities; the $\mathrm{j}=1$ to $n$

$\mathrm{Zj}=$ gross margin of a unit of the $\mathrm{j}^{\text {th }}$ activity (SDD/feddan)

Aij $=$ quantity of the $\mathrm{i}^{\text {th }}$ resource available (i.e., days of labour or other required quantities of inputs) required to produce one unit of the $\mathrm{j}^{\text {th }}$ activity

$M=$ Denotes the number of resources; then $i=1$ to $\mathrm{m}$

$\mathrm{Bi}=$ Amount of the $\mathrm{i}^{\text {th }}$ resource available (e.g. cubic meter of irrigation water, land area in feddans, days of labour or other required quantities of inputs).

The objective is to find the cropping system (defined as a set of activities levels $\mathrm{Xj}, \mathrm{j}=1$ to $\mathrm{n}$ ) that has the highest possible total gross $\operatorname{margin} \pi$, but doesn't violate any of the fixed resource constraints or involve any negative activity levels.

Equation (1) is the objective function, which maximizes the gross margins from one feddan of field crops.

Equation (2) shows the limits on the levels of the available resources (i.e., cubic meter of water, feddan of land, days of labour or other required quantities of inputs) that the tenant can apply to produce the mentioned crops.

Equation (3) which is a non-negativity condition, states that all resources used in the production process and output must be equal to or greater than zero, meaning that negative use of resources and negative production is not allowed.

The study also applied Partial Budget Analysis technique to assess the cost and returns of the crops under study. The basic data used to compute gross returns per fed are output values, while gross margin per fed was calculated by subtracting the average total operation cost (variable costs) from the average total returns. The general mathematical form for the gross margin calculation per crop is:

$$
\mathrm{GM}=\mathrm{GR}-\mathrm{TVC}
$$

Where:

GM: Crop gross margin per feddan in SDG,

GR: Crop gross revenue per feddan in SDG and

TVC: Crop total variable costs per feddan in SDG. 


\section{RESULTS AND DISCUSSION}

The Northern part of Sudan is characterized by a relatively unique cool winter compared to the rest of the country, which makes them the most suitable for the production of winter-season crops. Historically, the design of a comprehensive crop combination for each season, especially the winter season in River Nile State (RNS), is considered as a key factor to obtain a successful production and sustainable farming system. The winter season crop combination in RNS implies mainly cereal and legumes crops. In general, the nonlegume crops are considered a suppressing crop in the annual legume/non-legume intercrop system (Zhanget al., 2011). However, the performance of perennial legume and annual cereal intercropping varied by intercrop pattern (Abdel Magid et al., 1991). The tenants in the agricultural schemes of RNS seek every season to adopt relevant agricultural technology as well as a suitable crop rotation that contributes to irrigation water and land use efficiency and soil conservation. They look to apply advanced technologies to manage a reliable crop combination comprising cereal or grains such as wheat or leguminous crops like alfalfa and faba bean. A successful application of these modern technologies might lead to a successful winter season with high yield for field crops and hence will attain many goals. This at least may achieve the maximization of resource use which leads to poverty alleviation and food security in the agricultural rural areas of Sudan. Experiences in Sudan are of particular interest. Success in this country is clearly linked to the performance of the sprinkler irrigation systems and application throughout the country by foreign investment and the private sector. For example, the success of Al-Rajhi-Kafaa, Amtar and Arab Corporation for Agricultural Development schemes may be due in part to previous successful experiences and rational educated administration of the schemes that apply modern agricultural technologies and methods of working. This may be an important point

Table 1. Distribution of land resources in RNS to be borne in mind by developers when persuading farmers to change or take up modern systems. What is clear is that advanced systems are only accessible to schemes and farmers who can afford to purchase them and who are growing cash crops such as legumes, wheat, fodders, vegetables, and fruits providing sufficient returns to pay for the investment. Sudan's farmers will invest in modern technologies either to obtain enough finance or when the financial return is clear and relatively assured. Advanced systems in most developing countries have little to offer poor subsistence farmers and so are unlikely to be taken up by them.

\subsection{Agricultural resources management in River Nile State (RNS)}

Agricultural resources are essential components of crop production. In a world of limited resources, limited sympathy, and limited rationality, competition leading to tensions and conflict can arise. In such circumstances, a key responsibility of any society is to ensure the security of its citizens (Richard, 2009). Due to natural resources management complexity and scarcity, rationalizing and optimizing resources use becomes crucial to maximize the benefit from them. The scarcity of agricultural resources is exacerbated by limited agricultural land and limited water available for irrigation in case of expansion in new reclaimed land. Thus, the optimum crop combination should be considered to achieve and rationalize resource-consumption in order to increase farm income and save a large amount of irrigation water. It is possible that the farmed land area could be expanded thereby.

The River Nile State is considered as one of the main suppliers for agricultural production in Sudan (see Figure 1).

The total area of the state is about 129.744 $\mathrm{km}^{2}$ (30 million feddans) out of which about $3,249,000$ feddan is certified land for investment and suitable for multi agricultural activities and production (see Table 1).

\begin{tabular}{cc}
\hline Land resource & Area (feddan) \\
\hline Agricultural Arable land & $9,500,000$ feddan \\
Certified land for investment & $3,249,000$ feddan \\
Agricultural cultivated land & $1,200,000$ feddan \\
Forest land & 209,000 feddan \\
Natural pasture land & $48,000 \mathrm{~km}^{3}$ \\
\hline
\end{tabular}

Source: River Nile State (RNS) Ministry of Agriculture (2019) 


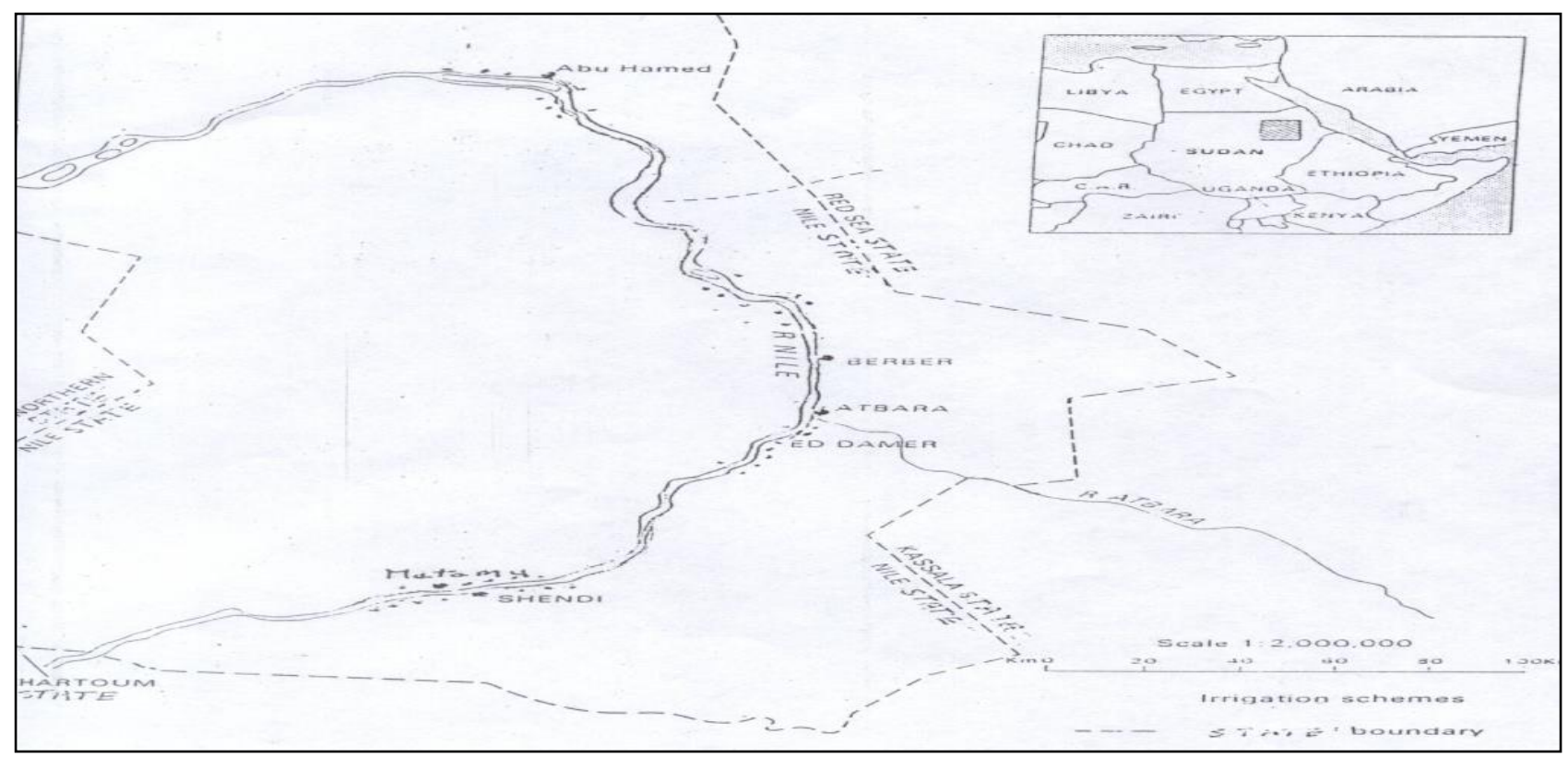

Figure 1. Map of the River Nile State of North Sudan

Source: Ahmed 2004

However, this research revealed that improved performance of resource management for agricultural production in the state is indicated. This is clearly seen in the gap between production potential and the targeted and cultivated areas in RNS for season 2017/2018. This might be due to resource misuse and inefficient management as shown in Figure (2). No doubt irrigation-water resource is one of the essential inputs for agricultural production. Sudan also is endowed with a sizeable amount of surface water resources with numerous sources.

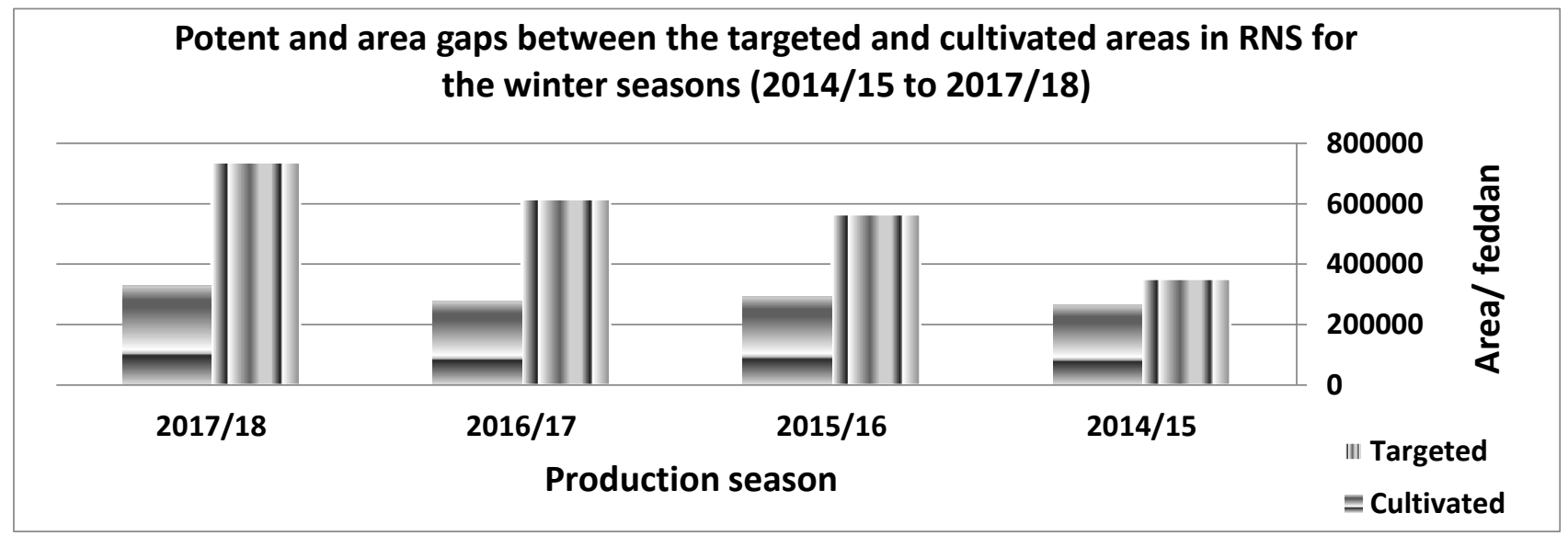

Figure 2. Area gaps and between the targeted and cultivated areas in RNS

Source: River Nile State (RNS) Ministry of Agriculture (2019).

The utilization of this water is still under the umbrella of the Nile Waters Agreement (NWA) (1959) signed between Sudan and Egypt. NWA is based on the average annual flow of 84 billion $\mathrm{m}^{3}$ measured at Aswan shared as follows: The Sudanese share 18.5 milliard $\mathrm{m}^{3}$, Egyptian share $55.5 \mathrm{bm}^{3}$, and the losses due evapotranspiration and others in Aswan district were estimated at $10 \mathrm{bm}^{3}$. In addition, the State has underground water in the Nubian Sand Stone. 
Table 2. The main direct resources of irrigation water in RNS

\begin{tabular}{ll}
\hline Water source & Water amount \\
\hline River Nile along the RNS & $670 \mathrm{~km}^{3}$ \\
Atbara River & $200 \mathrm{~km}^{3}$ \\
Underground water aquiver & $3,16 \mathrm{milliard} \mathrm{m}^{3}$ \\
Surface water and valleys & 1,490 milliard $\mathrm{m}^{3}$ and \\
from rainfall & 57 valley \\
\hline
\end{tabular}

Source: Report of Ministry of Agriculture in RNS season 2017/2018.

The River Nile State is one of the relatively rich states in the country in terms of water resources.

Table 3 Cultivated area of crops in the River Nile State in season 2016/17

\begin{tabular}{llll}
\hline Crop & Area (fed) & Production (ton) & Price (SDG/ton) \\
\hline Wheat & 38,281 & 49766 & 5500 \\
Faba bean & 30,611 & 10408 & 17500 \\
Kidney bean & 10,875 & 4133 & 27500 \\
Chickpea & 3,728 & 1492 & 19000 \\
Potatoes & 14,773 & 92332 & 28000 \\
Onions & 54,184 & 915710 & 3250 \\
Vegetables & 17,315 & 110555 & 22200 \\
Fodders & 26,086 & 42816 & 900 \\
Spices & 6,086 & 59244 & 85575 \\
Sorghum & 12,917 & 30799 & 3830
\end{tabular}

Source: Source: River Nile State (RNS) Ministry of Agriculture (2019)
On the other hand, available information unveils that the total cultivated area of Al-Rajhi-Kafaa scheme is about 19,500 feddans distributed among 156 pivot sprikiler units. The allocation of the field crops in the scheme was such that $40 \%$ of the total cultivated land was occupied by wheat, followed by $30 \%$ for alfalfa, while $20 \%$ and $8 \%$ went for maize and sunflower, respectively.

This paper observed that most of the cultivated areas were covered by cereal crops which are known as very exhaustive to soil fertility, while legumes and vegetable crops that able to fix nitrogen to soil formed a limited area of the scheme indicating negligence of land improvement to produce food security products and of soil conservation. The majority of these crops are cultivated as winter crops with exceptional cases for some crops that could be produced in winter and summer seasons, namely maize, fodder, and vegetables. Furthermore, sorghum atEl-Zeidabpublic scheme is usually sown at the end of the summer season (September) to be harvested in the middle of the winter season (January), while sorghum and onions are grown in April after wheat harvest and continue to be irrigated with wheat. The
The main direct resources of irrigation water in RNS are the River Nile, Atbara River, underground water, and rainfall (see Table 2).

\subsection{Cultivated areas in River Nile State (RNS)}

The distribution of field crops in the River Nile State season 2016/17 was such that the majority of the total land was devoted to onions, followed by wheat and faba bean, while the lowest percentage was allocated to chickpea. The other crops were ranked as illustrated in Table (3). harvested crops are used either for domestic consumption and/or as cash crops.

\subsection{The predominant irrigation systems in the area of the study}

The sustainability of irrigated agriculture is under a challenge to raise water productivity. The shortage of fresh water has become a worldwide phenomenon. Numerous constraints are facing supplies of fresh water not only in the Middle East and Africa, but also in some Asian countries, and even in Northern America. Scarcity and lack of water quality are becoming a threat to national security in these countries as the problem of water deficit increases. They are trying to solve it by using a variety of techniques such as: Water Export Agreements (i.e. Belarus and the United Arab Emirates, Turkey and Israel, Kyrgyzstan and Germany), modern saving technologies, desalination, and others. In many subSaharan African countries demand for water is increasing due to the rapid growth of population.

\subsubsection{Elkafaa of Al-Rajhi Scheme:}

The farm management in Elkafaa is fully under the administrators' control, while the 


\section{Elgilany A. Ahmed and Hamid Hussein M. Faki., 2020}

government is considered a supervisor and tax collector. Power sources in Elkafaa of the Al-Rajhi scheme are diverse. They include diesel generators, public electricity, and solar energy. Elkafaa consists of 10 big irrigation pump stations; the average pivot sprinkler (PS) per station is 8. Eight of these ten irrigation pump stations include about 67 PS, while the remaining two stations include 12 PSs or six PS in each station. The total of the PS in the 10 stations of the scheme is about 75 PS, besides the 10 stations there are about 26 small stations and there are 26 PS or one PS for each station resulting in the total employed PS in the scheme by 101 PS. The allocated land for each PS is about 60 hectares (142.8 feddan).

The State has numerous types of irrigated schemes such as the public irrigated schemes, foreign investment schemes, agricultural companies,private and cooperative schemes with different farming systems and production relationships. As mentioned before, the research selected two different types of irrigated schemes. One is El-Zeidab public irrigated scheme, which represents the conventional irrigation systems in the state. The other one is the Elkafaa-AlRajhi scheme that represents the modern irrigation systems in the area of the study.

\subsubsection{Al-Zeidab Public Irrigated Scheme:}

The farm management in the Al-Zeidab scheme is under the control of the scheme tenants, while the government is responsible for selling the crop and supplying irrigation water, besides preparation of agricultural policies. The Al-Zeidab scheme has 5 irrigation pump stations, each employing 14 pumps with different sizes that range between 12 36 inches. The total discharge of these pumps was estimated at $22 \mathrm{~mm} / \mathrm{s}$, equal to $80000 \mathrm{~mm} / \mathrm{hr} / \mathrm{pump}$ lifted directly into the supply canals. About 78 percent of the total delivered water per watering was devoted to the field crops with an area of 11,700 fed equal $61,776 \mathrm{~mm} / \mathrm{hr} / \mathrm{pump}$, while the remaining amount is allocated to the perennial crops. The average daily pumping duration of the pump station is estimated at 8-10-12 hours for the scheme, throughout the production season. The total quantity of the delivered water per irrigation for Al-Zeidab scheme was estimated at 8,864,640 mm including water losses; this amount is supplied for 14,700 feddans for both perennial and field crops when they exist simultaneously.

The area of the study is located in the Northern region of Sudan; it has endowed with a large irrigable the fertile land that estimated as 2.79 million ha in the last decade. About 1.86 million ha of the total area is equipped for irrigation; while the actual irrigation-equipped area is estimated only at $43 \%$. The potent of irrigated area is exists in the central and the northern states of the country. Nowadays there is a real need to raise the farmer's awareness regards to advance irrigation water technologies and its importance in water use efficiency as for crop productivity. The perception of this conception in the agricultural sector of the State will ease and disseminate the adoption of modern irrigation technologies. The delivery of irrigation water for the schemes under this study depends mainly on pump irrigation system from the River Nile through fixed irrigation stations at the river and thus via net canals. The winter season is considered as the principal season in the State, while the summer and autumn "damira" seasons are ranked after winter due to some climatic factors and economical aspects.This gives a comparative advantage for the winter crops combination versus other annual field crops. The research focused on the alfalfa crop as one of the important cash crops in the area of the study.

\subsection{Alfalfa fodder legume crop production relation in RNS}

Agricultural production relations in River Nile State are variable and varied. Those in the private pump schemes are unique. The small farmers there have to pay part of their produce in return for irrigation water alone, or in some cases, irrigation plus other services provided by the owner of the water pump. The proportion that the small farmer should paid usually differs according to the type of crops grown, land ownership, soil quality, and obligations agreed upon between the two partners (Ijami, 1994). The public schemes in RNS include holdings of various sizes whose operators may be owners or tenants. Water is delivered to the land by the administration of the scheme which owns the pumps and canals of these schemes, and the farmers are billed the cost of water (Mahmoud, 1982). In RNS the most dominant procedure is allocation of one-seventh of the crop output for the land, while the remaining output is shared equally between the pump owner and the small farmer. Based on this agreement, and according to whether the crop grown is a low or a high-value crop, the pump owner may pay or share the cost of inputs with the farmer such as fertilizer, pesticides (Ijami, 1994). The production relations in the schemes of the study are absolutely different. In the El-Zeidab scheme, the relation has been based on a water rate system subject to an agreement between farmers and scheme administration. The scheme water charges 
differ between field and perennial crops. In Al-RajhiKafaa irrigated scheme the situation is different as mentioned early; however, the crop production operations and processing have been managed by the scheme administration as mentioned before.

\subsection{Analysis of alfalfa costs and returns}

Generally, the economics of production is regarded as a fundamental role in enterprise and farm management. Production costs are known as the cost of inputs, labor, services, and the management used in producing a particular commodity or crops. Numerous researches indicated that the high cost of crop production in the River Nile State has contributed to low profit. The research showed that most of the tenancy operations in the El-Zeidabpublic irrigated scheme were handled by the scheme's farmers and/or their relatives, while hired labours were usually needed for labour-intensive operations such as land preparation and harvest. In large-scale private schemes the situation is different. In this study case of the AlRajhi-Kafaa scheme farm machineries are used for most of the production operations with low numbers of labours. Figure (2) illustrates the cost components within the sequence of production operations of annual crops in the two study schemes. It is clear that the majority of the variable cost components of producing annual crops in the El-Zeidab scheme exceeded those at Al-Rajhi-Kafaa.The high cost in the public scheme of RNS could be justified with such as lack of application of advanced technologies as well as the large scale of production. Generally, the Al-RajhiKafaascheme is characterized as being a fullmechanized scheme with large-scale production, contributing significantly to decreasing the operation cost of the scheme in contrast to the case of the ElZeidab scheme.

The research employed a gross margin analysis technique to assess alfalfa returns. Gross margin is considered as one of the good indicators of how profitable a farm or a firm at the most fundamental level. Farms or enterprises with high gross margins will have abundant resources to invest in future activities such as production and marketing promotion.

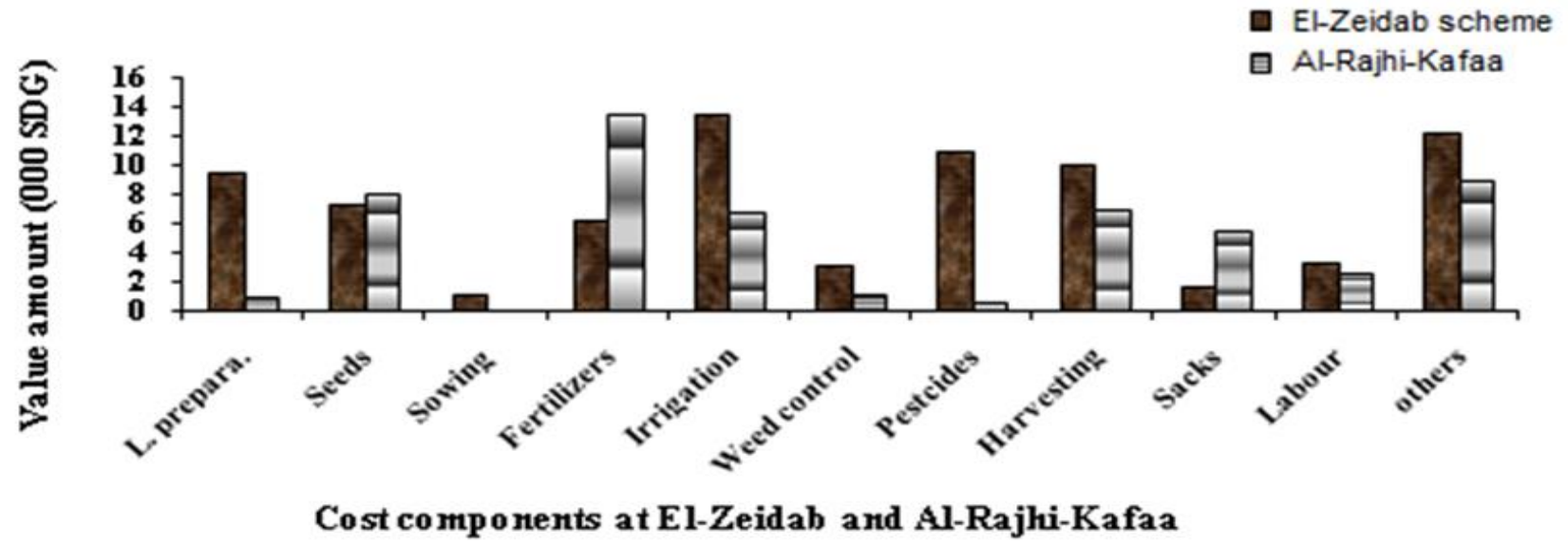

Figure 2. Average cost components for Alfalfa crop in area of the study

The past few decades have witnessed the increase awareness of its value and benefits. Gross margins for of global demand for alfalfa fodders with increasing alfalfa under study were assessed in Table (4).

Table 4. Gross margin analysis for alfalfa at Al-Rajhi-Kafaa\&El-Zeidab

\begin{tabular}{|c|c|c|c|}
\hline Budget component & $\begin{array}{l}\text { Alfalfa returns } \\
\text { Kafaa(SDG/year) }\end{array}$ & Al-Rajhi- & $\begin{array}{l}\text { Alfalfa returns } \\
\text { (SDG/year) }\end{array}$ \\
\hline Production cost (SDG/fed) & 4,200 & & 3,800 \\
\hline Average yield (kg/fed) & 7,560 & & 6,206 \\
\hline Average price (SDG/kg) & 3.00 & & 3.0 \\
\hline Gross returns (SDG) & 22,680 & & 18618 \\
\hline Gross margins (SDG) & 18,480 & & 14,818 \\
\hline
\end{tabular}

Source: The field survey 2006 
Gross margins of the crop were positive in the two schemes of the study as depicted in Table (4), but with a variation. Al-Rajhi-Kafaa could attain the highest gross margins for alfalfa reaching about SDG 18,480 compared to SDG 14,818 obtained by El-Zeidab tenants. Furthermore, with yield improvement of alfalfa crop grown in the El-Zeidab public scheme, still higher gross margins can be obtained in case they introduce advanced technology and effective agricultural management.

In general, farm income in the public irrigated schemes of RNS is low. Alfalfa growers in these schemes need more awareness regarding modern technologies, farming system management, and market promotion within marketing issues. The research revealed that the alfalfa growers in the River Nile State may adopt modern irrigation technologies instead of the conventional ones to obtain high crop yield and returns; this also will encourage farmers to expand alfalfa cultivated area due to the mentioned benefits.

\subsection{Irrigation water management in El-Zeidab and Al-Rajhi-Kafaa}

The demand for good-quality water is continuously rising owing to the rise in the population, intensive agricultural practices, industrialization, and the overall rise in living standards (Srinivas et al, 2009). Many research unveiled that irrigation water in agriculture represents about $70 \%$ of global fresh water use. The method developed in this research utilizes the statistics obtained from Ministry of Agriculture of RNS, Al-Rajhi-Kafaa scheme reports, and economic modeling to design a more reliable data set for RNS and resources use in its irrigated schemes by combining as far as possible the obtained data from the areas of the studies, prevalent cropping patterns and irrigation systems to evaluate the amount of cultivated land and irrigation water applied.

\subsection{Crop Water Requirements (CWR) in the Area of Study}

Extensive researches were carried out in the field of irrigation water use for a range of perennials and field crops. These researches aimed to facilitate the accurate estimate of irrigation requirements of the mentioned crops on the basis of climatic and standardized crop data. Combined with soil water balance calculation, a range of computer programs such as the FAO CropWat4 program exist to determine irrigation schedules, assuring accurate and efficient water supply. The predominant conception of irrigation requirements (IR) refers to the water that must be supplied through the irrigation system to ensure that the crop receives its full crop water requirements. This research adopted the Food and Agriculture Organization (FAO) method for computing crop water requirements (CWR); from the calculation of crop coefficient $(\mathrm{kc})$ to the estimation of irrigation diversion requirements. The FAO computer software program entitled 'CropWat4' was applied, using its associated database of climatic data for key stations around the world for the main annual crops namely, wheat, maize, and alfalfa in the area of the study. The obtained results are shown in Table (5).

Table 5. Determination of $\mathrm{CWR} / \mathrm{ha}$ for the main field crops in the area of the study

\begin{tabular}{llcc}
\hline Crop & ETo $\left(\mathbf{m}^{\mathbf{3}}\right)$ & Kc & $\begin{array}{c}\text { CWR } \\
\left(\mathbf{m}^{\mathbf{3}} / \mathbf{h a}\right)\end{array}$ \\
\hline Wheat & 1.81 & 1.82 & 5,750 \\
Maize & 1.86 & 1.9 & 6,216 \\
Alfalfa & 6.00 & 1.7 & 17,460 \\
\hline
\end{tabular}

Source: calculated by the authors 2018

Table (5) depicts the results computed by using the FAO CropWat4 software program. It is clear that the CWR for the field crops in the areas of the study varies according to the prevalent climatic factors.

\subsection{Irrigation water supply in the schemes of the study}

The amount of on-farm supplied water was already computed by specialists working at the Ministry of Agriculture and Irrigation in the State. This quantity is estimated as $588 \mathrm{~mm} /$ fed per watering for the public irrigated schemes in the State including about $3 \%$ losses for both seasonal and perennial crops. On the other hand, the applied irrigation water amount was adjusted according to the type of crop and hence was calibrated for the crop combination in Al-RajhiKafaa irrigated scheme. The main source of irrigation for El-Zeidaband Al-Rajhi-Kafaa schemes is mainly the River Nile. Irrigation water supply at the Al-RajhiKafaa scheme is characterized as a dailyapplication and the watering period was in the range of $16-20$ $\mathrm{hr} /$ day for the field crops grown in the scheme namely, alfalfa, wheat, and maize. 
Scientific Journal of Agricultural Sciences 2 (2): 240-255, 2020

Table 6. Wheat and alfalfa crops basic data in Al-Zeidab public scheme

\begin{tabular}{llllll}
\hline Crops & Growing Period (days) & $\begin{array}{l}\text { No. } \\
\text { waterings }\end{array}$ & $\begin{array}{l}\text { of Term } \\
\text { irrigation(hours/fed) }\end{array}$ & $\begin{array}{l}\text { of Irrigation } \\
\text { Interval (days) }\end{array}$ & $\begin{array}{l}\text { Water } \\
\text { (SDG/fed) }\end{array}$ \\
\hline Alfalfa & 1460 & 24 & 5.5 & 15 & 1000 \\
\hline
\end{tabular}

Source: field survey

The research revealed that the computed irrigation water charge in the Al-Rajhi-Kafaa scheme in season 2016/2017 was 200 SDG for wheat and 1000 SDG for alfalfa, while the impact of rainfall is neglected in the irrigated agriculture sub-sector of RNS due to its small amount. The general characteristics of alfalfa fodder legume crop under study are summarized as average quantities as stated by the interviewed tenants in Table (6). Table (6) also illustrates the distribution of alfalfa growing period.Alfalfa stays 1460 days as the longest duration among the dominant field crop combination in ElZeidabscheme. The number of watering varied among the field crops of the scheme, being about 7 watering for cereals such as wheat while alfalfa received about 24 watering. The time taken per irrigation was 4.8 hours and 5.4 hours for cereals (i.e. wheat) and alfalfa,

respectively. The average irrigation interval was 15 days for each of the crops in the scheme. The annual water charge was fixed by the scheme administration at 1000 SDG for alfalfa and 200 SDG for other field crops such as cereals. In assessing the on-farm water use efficiency (FWUE) of alfalfa, the calculated FWUE covered mainly two levels of irrigation: per watering and per season. The annual average water application for alfalfa in El-Zeidabwas derived as about $9,023 \mathrm{~m}^{3}$ due to its long period as a perennial crop while that for wheat was about $3,756 \mathrm{~m}^{3}$. The study found that the average water application for the other field crops per season was $8,820 \mathrm{~m}^{3}, 3,426 \mathrm{~m}^{3}$, and $2,352 \mathrm{~m}^{3}$ for onion, sorghum and abu-sabaeen forage crop, respectively. Table (7) depicts FWUE per watering and season for alfalfa in the scheme.

Table 7. FWUE per watering and season for alfalfa in El-Zeidab

\begin{tabular}{lllllc}
\hline Crop & $\begin{array}{l}\text { CWA } \\
\left(\mathrm{m}^{3} / \mathrm{fed}\right)\end{array}$ & $\begin{array}{l}\text { iWUE per } \\
\text { watering }\end{array}$ & $\begin{array}{l}\text { ver-irrigation } \\
(\%)\end{array}$ & $\begin{array}{l}\text { FWUE } \\
\text { season }\end{array}$ & $\begin{array}{l}\text { per Over-irrigation } \\
(\%)\end{array}$ \\
\hline Alfalfa & 9023 & 0.46 & 54 & 0.81 & 19 \\
\hline
\end{tabular}

Source: The field survey

Table (7) shows that the the FWUE for alfalfa crop of the El-Zeidab scheme is relatively high and indicating increase water demand per watering throughout its growing season. Furthermore, the estimated FWUE of the El-Zeidab scheme indicated a wide technical gap between the required amount of

water and the actual water supply. The Table also unveiled that the FWUEs per watering were 0.46 for alfalfa and the FWUE per season amounted to as high as 0.81 . This shows clearly that the tenants within ElZeidabsurveyed sample over-irrigated their field crops.

Table 8. On-farm irrigation water-use efficiency at Al-Rajhi-Kafaa

\begin{tabular}{|c|c|c|c|c|c|c|}
\hline Crop & $\begin{array}{l}\text { Growing } \\
\text { (day) }\end{array}$ & $\begin{array}{l}\text { Supplied water }\left(\mathrm{m}^{3} /\right. \\
\text { ha)/year }\end{array}$ & $\begin{array}{l}\text { Annual } \\
\left(\mathrm{m}^{3} / \mathrm{ha}\right)\end{array}$ & CWR & FWUE /year & $\begin{array}{l}\% \text { Over } \\
\text { irrigation }\end{array}$ \\
\hline Alfalfa & 290 & 22,185 & 17,460 & & 0.79 & 21 \\
\hline
\end{tabular}

Source: The field survey (2017).

On the other hand, FWUE in the Al-RajhiKafaa scheme was shown in Table (8). The distribution of crop growing periods revealed that

alfalfa stays for 290 days with a longer duration compared to other field crops.

Table 9. FWUE per watering and season for the schemes' crops of the study

\begin{tabular}{lcclc}
\hline Scheme & $\begin{array}{c}\text { FWUE/ } \\
\text { watering }\end{array}$ & $\begin{array}{c}\text { Over/under } \\
\text { irrigation } \%\end{array}$ & $\begin{array}{l}\text { FWUE/ } \\
\text { season }\end{array}$ & $\begin{array}{l}\text { Over/under } \\
\text { irrigation\% }\end{array}$ \\
\hline FWUE El-Zeidab & 0.41 & $(+) 59$ & 0.62 & $(+) 38$ \\
\hline FWUE Al-Rajhi-Kafaa & 1.1 & $(-) 10$ & 1.1 & $(-) 10$ \\
\hline
\end{tabular}

Source: The field survey (RNS)

The research also found that the annual Kafaascheme was about $8,050 \mathrm{~m}^{3}$ exceeding those of average water application for alfalfa in the Al-Rajhiall the grown field crops in the scheme due to the 


\section{Elgilany A. Ahmed and Hamid Hussein M. Faki., 2020}

same justification in the El-Zeidab scheme where the average water application was $2,275 \mathrm{~m}^{3}$ for onion as the highest amount, followed by $1,925 \mathrm{~m}^{3}$ and 1,750 $\mathrm{m}^{3}$ for wheat and sorghum respectively while the lowest water amounts for abu70 forage crop was 1,225 $\mathrm{m}^{3}$. The FWUE for Al-Rajhi-Kafaa field crops is relatively low when compared to El-Zeidabfield crops and also to their water requirements except for the case of alfalfa indicating water shortage through their growing season. Furthermore, the estimated FWUE of the Al-Rajhi-Kafaascheme indicated negative technological gaps between the required utilization and actual water application for most of the field crops, while FWUE for the Al-Rajhi-Kafaaper watering was found to be 0.89 for alfalfa as the lowest FWUE, while it was 1.4 for abu70 forage as the highest FWUE, followed by 1.3, 1.2 and 1.1 for wheat, sorghum and onions, respectively. On the other hand, FWUE per season amounted to as high as 1.3 for abu70 forage; followed by 1.2 for each of wheat and sorghum and 1.1 for onions, while it was as low as 0.9 for alfalfa. This implies that the administration of the Al-Rajhi-Kafaa scheme under-irrigated its field crops by $20 \%$ as the cases of wheat and sorghum and by $30 \%$ for abu 70 forage, while alfalfa was overirrigated by $10 \%$. These results have fundamental policy implications such that, improving FWUE for the annual crops under the schemes of the study to contribute to the overall FWUE in the region. The estimated surplus water at Al-zeidab public irrigated scheme would be sufficient for expansion to newly irrigated area in the scheme. The irrigation water supply in Al-Rajhi-Kafaa is on the other hand characterized by irrigation shortages for most annual crops.

\subsection{Water productivity for alfalfa crops in RNS}

Yield and water productivity can be sustainably improved with the application of supplemental irrigation in the rain-fed areas, the adoption of water harvesting in the steppe areas, and the use of improved irrigation systems and schedules in irrigated areas (Shideed et al, 2005). ICARDA (2005) defines water productivity as the ratio of crop production $(\mathrm{kg})$ to the unit of water used $(\mathrm{mm})$ or as the amount of food produced per unit volume of water used, while economic productivity is defined as the net present value of the product divided by the net present value of the amount of water diverted or depleted (defined in terms of its value or opportunity cost in highest alternative use). Generally, ICARDA reports that there are several different ways for expressing water productivity (WP) such as pure physical productivity or combined physical and economic productivity, but the majority of the researchers frequently use the term water productivity as the ratio of physical crop yield and the amount of water consumed. Productivity is expressed as a mass ( $\mathrm{kg}$ or ton) and the amount of irrigation water as a volume $\left(\mathrm{m}^{3}\right)$. The determination of productivity per unit water (WP) for Al-Zeidab and Al-Rajhi-Kafaaannual crops of the study was based onphysical water productivity as presented in Table (10). As research facts, numerous techniques can be used to achieve high water productivity, this can be through promoting water use efficiency (WUE) techniques, adopting advanced irrigation technologies for effective on-farm water use, selection of proper crop combination, cultural practices, and adopting suitable crop varieties.

Table 10. Yield and WP for alfalfa in physical and monetary terms

\begin{tabular}{|c|c|c|c|c|c|c|}
\hline Crops & $\begin{array}{l}\text { Yield } \\
\text { (kg/fed) }\end{array}$ & $\begin{array}{l}\text { Research yield } \\
(\mathrm{kg} / \mathrm{fed})\end{array}$ & $\begin{array}{l}\text { Yield Gap } \\
\%\end{array}$ & $\begin{array}{l}\text { WP } \\
\left(\mathrm{kg} / \mathrm{m}^{3}\right)\end{array}$ & $\begin{array}{l}\text { Water price } \\
(\mathrm{SDG} / \mathrm{Fed})\end{array}$ & $\mathrm{WP}\left(\mathrm{SDG} / \mathrm{m}^{3}\right)$ \\
\hline Alfalfa (Zeidab) & 6,206 & 8,500 & $26 \%$ & 0.69 & 1000 & 0.1 \\
\hline Alfalfa (Kafaa) & 7,560 & 8,500 & $11 \%$ & 11.9 & 480 & 0.1 \\
\hline
\end{tabular}

Source: The field survey (RNS)-2017/2018

47.5 $\mathrm{SDG}^{2}=1 \mathrm{US} \$$

From Table (10) the technical method for assessing physical water productivity derived as $\mathrm{kg}$ of output per $\mathrm{m}^{3}$ of water was generally low for $\mathrm{Al}$ Zeidab field crops while it is high in the Al-RajhiKafaa scheme. Table (10) shows that the water productivity was high for the Al-Rajhi-Kafaa alfalfa crop and it was found low for Al-Zeidab one indicating very high irrigation water use efficiency under Al-Rajhi-Kafaa modern irrigation systems represented by the pivot sprinkler system. This may confirm the fact that points to the ability of advanced irrigation technology to manage irrigation water efficiently.

\subsection{Assessment of resources Use for Wheat and Alfalfa Production}

Availability of agricultural resources, especially land and irrigation water form essential preconditions for successful agricultural investment in different cash, food products, and their commercialization. The 


\section{Scientific Journal of Agricultural Sciences 2 (2): 240-255, 2020}

long history of experience in perennials and annual crop production in the country have provided a broad and strong background for Sudanese farmers to manage their farming system to produce various food and cash crops. The combination of annual crops and livestock herding offers promising options for promoting the farming system and improving the livelihoods of rural people. Yet, the high competition for fresh water and fertile land increases the complexity of natural resource use and management. The high cost of production coupled with low productivity and lack of a cheap source of power has made it difficult for farmers to realize the full potential of the region. In fact, agricultural resources are available for increasing agricultural production and raising the living standards of the rural poor. Generally, in River Nile State of north Sudan crop productivity potential within the agricultural sector come from the irrigated sub-sector. Then the important question here is how to balance the use of available agricultural resources in the area of study? Thus agricultural resource-use efficiency might be an appropriate indicator to build on within the existing circumstances.

\subsection{Alfalfaand optimal cropping pattern and returnsin RNS}

The model run in this research provides information and results on the objective function value under optimal crop combination and resources used accompanied by their respective marginal value productivities. The actual and optimal cultivated land for the dominant perennial crops combination is presented in Table (13). From the table, the optimal solution reflects devoting land only for alfalfa (at 5 feddan), while the rest of the crops including fruits didn't appear in the optimal plan. The actual returns from crop production amounted to SD 134998 compared to SD 255215 under the optimal solution; an increase of $89 \%$.

Table 13. resources use and cropping pattern plan for Alfalfa in RNS

\begin{tabular}{llll}
\hline Item & Actual & Optimal & Units \\
\hline Resources use: & & & \\
Total land & 10 & 5 & Fed \\
Total irrigation water & 65613.75 & 45120 & Cubic meter \\
Total labor & 101 & 60 & Man-day \\
Total capital & 960108 & 737760 & SDG \\
Returns: objfn value (Z) & 134998 & 255215 & SDG \\
\hline Cropping pattern: & & & \\
Date & 1.23 & - & Fed \\
Citrus & 5.01 & - & Fed \\
Alfalfa & $\mathbf{1 . 7 2}$ & $\mathbf{5}$ & Fed \\
Mango & 0.75 & - & Fed \\
Guava & 1.29 & - & Fed \\
\hline Source: & & &
\end{tabular}

Source: Model results (RNS)

The last decades witnessed increased interest to grow perennial crops overall the RNS as well as the northern state, and that might be due to the higher prices and/or the low operation costs of those crops when compared to the annual crops according to their time occupation of land. In fact, the higher prices for perennial crops have provided incentives and justifications to grow them. Moreover, growing of perennial crops allows their intercropping by some crops particularly alfalfa. According to the mentioned characteristics of the perennials, the resources use and availability might be under competition. The actual and optimal levels of the resources depicted in Table (13) reflect that $50 \%$ of the available land should be used for alfalfa apparently due to its high returns compared to other perennial crops.
The tenant's practices with respect to crop area allocation reflect a dominant trend towards a diverse crop combination in an attempt to utilize as much as possible the resources available to them. More importantly, this trend has been most likely followed based on long-term experience of farmers to reduce agricultural risks.

\subsection{Resources use and constraints for alfalfa crop}

The disappearance of the other perennials in the optimal solution raises concerns about the need for efforts, including appropriate policies, to improve their productivity, as justified by research results, and set their market prices right. This is justified by the forementioned advantages of the other perennials (date palm, citruses, mangoes, and guava) in people's 


\section{Elgilany A. Ahmed and Hamid Hussein M. Faki., 2020}

livelihood and the actual expansion in their areas. On the other hand, the simplified model - due to lack of information - did not capture issues that would have raised the other perennials' gross margins such as their by-products and the expected notable value of crops that can actually be grown underneath the trees. Furthermore, the other perennials are associated with low risks of perishability, long storage potential, and low transport costs compared with other fruit plantations. The model also assumes that the demand for alfalfa is highly inelastic and that there are no constraints on its markets.

\subsection{Sensitivity analysis}

The model solver used here to perform the case for scenario analysis by changing the model data and then solving the same model again.

\subsection{Impact of increasing the available cash of tenants by $50 \%$}

The low availability of cash and the weakness system of finance regarded as chronic constraints in the area of study. The devoted cash for producing perennial crops is assumed to be increased by $50 \%$ from governmental financial institutions or/and international organizations. The impact of this assumption is represented in Table 14 .

Table 14. Impact of increasing the available cash of surveyed tenants by $50 \%$

\begin{tabular}{llll}
\hline Item & Actual & Optimal & Units \\
\hline Resources use: & & & \\
Total land & 10 & 5 & Feddan \\
Total irrigation water & 65628 & 45120 & Cubic meter $\left(\mathrm{m}^{3}\right)$ \\
Total labour & 101 & 60 & Man-day \\
Total capital & 1440162 & 1440156 & SD \\
Returns: objfn value $(\mathrm{Z})$ & 134998 & 255215 & SD \\
\hline Cropping pattern: & & & \\
Date & 1.23 & - & Feddan \\
Citrus & 5.01 & - & Feddan \\
Mango & 0.75 & - & Feddan \\
Guava & 1.29 & - & Feddan \\
Alfalfa & 1.72 & 5 & Feddan \\
\hline
\end{tabular}

Source: Model results, 2008

Table 14 indicates the impact of increasing the available cash of area of the study and the importance of the State intervention to solve the hindrances of the low availability of cash and the weakness system of finance which is considered as chronic constraints in the area of study, the mentioned impact of increasing cash appears in the following:

a. The optimal solution of the objective function is more than the objective function in the basic solution by $89 \%$.

b. The optimal irrigation water, land, labour, and capital are less than those in the basic solution by $50 \%, 31.24 \%, 40.60 \%$, and $.0004 \%$, respectively, while the distribution for the optimal cultivated area over the crop combination was 5 fed covered by alfalfa.

c. Table 14represents the optimal solution for the resources used. It ensures the importance of financing of the farming system in the area of the study will increase farm investment and application of modern technologies for agricultural production.

\section{Conclusion and policy implications}

This research presents some of the findings of the field survey for public and private schemes surveyed in the RNS of the Northern Region. It described the dominant irrigation systems and emphasized on the essential of irrigation water management for producing the main field food and cash crops in the region and conclusion drawn obtained from numerous analytical tools found that:

(1) The farmers of the El-Zeidab scheme exceeded the field crop water requirements per watering for the entire season; this is might suggesting high potential for irrigation water use in case FWUE is improved, while the Al-Rajhi-Kafaa scheme administration decreasing the field crop water requirements by $10 \%$ per watering and for the entire season is suggesting a shortage for irrigation water use. 


\section{Scientific Journal of Agricultural Sciences 2 (2): 240-255, 2020}

(2) The tenants in the public irrigated schemes represented by El-Zeidab public scheme applying conventional irrigated systems at low technology levels and they were at low feasible production options in their field crops. That is clear in their levels of yield and rates of returns which are relatively low compared with the crop production at the modern irrigation system at $\mathrm{Al}-$ Rajhi-Kafaa scheme. This is an obvious indication that research impacts and efforts are successful in the development of improved technology for the production of important and strategic crops in the farming systems of RNS.

(3) The physical water productivity derived as $\mathrm{kg}$ of output per $\mathrm{m}^{3}$ of water was generally low for ElZeidab field crops while it is high in Al-RajhiKafaa one.

Based on the obtained results the research proposed the following recommendations:

(1) There is a high potential for improvement to save valuable amounts of fresh water that can be used to extend new irrigated areas. The intervention of the government is needed to ease irrigation-water management and availability to improve water-use efficiency by changing or modernizing the existing conventional irrigation system, adoption of the recommended water use technologies, and introduction of modern irrigation technologies.

(2) The paper is confirmed that introducing modern irrigation technologies like pivot sprinklers, floppy, and drip systems are more economical and efficient than the traditional ones such as surface system. Since it lowers the water costs, it releases more financial resources to adopt and update other modern irrigation technologies.

(3) Updating of production policies among resource owners, out operator growers and the State financial institutions will ease to regulate access and influence advance technologies use.

(4) Adoption of a participatory approach by the scheme administrators and farmers in the agricultural schemes in the region to manage irrigation water is a big challenge and incentive at the same time for farmers to adopt modern water-saving technologies.

(5) Raising and updating the administrators' and farmers' awareness in both traditional irrigation systems and modern irrigation systems about the importance of water for agriculture, life and environment through an efficient structure that can be applied by the extension system.

\section{REFERENCES}

Abdel Magid HM (1991). Productivity of wheat and alfalfa under intercropping. Exp. Agr. 27, 391-395.

Ahmed EA (2004). Economics of Faba bean Production and Marketing in River Nile State. A Case Study Elddamer District. M.Sc. Thesis, University of Khartoum.

Ahmed EA (2009). Economic Aspects and Water Use Efficiency in Public Pump Irrigated Schemes of the River Nile State. PhD. Thesis, University of Khartoum.

Abdella AA (1995). The Agricultural Potential of Sudan. EIR Volume 28, Number 8, February 23, 2001.

Guiguo Zhanga b, Zaibin Yangb, Shuting Donga (2011). Interspecific competitiveness affects the total biomass yield in an alfalfa and corn intercropping system.

ICARDA (2005). A report on Collaborative research under taken by: The International Center for Agricultural Research the in dry Areas (ICARDA) and The United Nations Economic and Social Commission for Western Asia ESCWA.

Ijami AA (1994). Efficiency and equity Effects of Market Access on Agricultural productivity in Sudan. A Case Study Small Holder Along the R.

Richard Bowen W (2009). 'Water engineering for the promotion of peace". 1944-3994 / 1944-3986 (C) 2009. Desalination Publications. doi: 10.5004/dwt.2009.170. 1 (2009) 1-6. 2009.

Shideed KT, Oweis TY, Gabr M, Osman M (2005). Assessing On-Farm Water-Use Efficiency: A new Approach. Methodology and Six Case Study. In A report on Collaborative research undertaken by KARDA and ESCWA, Aleppo, Syria.

Srinivas G, Sekar S, Saravanan R (2009). Renganaray- -anan, S. "Studies on a water-based absorption heat transformer for desalination using MED". 1944-3994/1944-3986 (C) 2009 Desalination Publications.1 (2009) 75-81.

Ismaiel Ahmed (2019). A case study on sorghum supply chains in three farming systems in the Republic of Sudan

Faki HH, Idris M, Elsir A (2004). Irrigated Benchmark Site Project for Sudan. Agricultural Research Corporation, Wad Madani (2004).

Ahmed A. Elgilany (2009). Economic Aspects and Water Use Efficiency in Elzeidab and Elketiab Schemes of the River Nile State. A Thesis Submitted to the University of Khartoum for fulfillment of the Requirements of the Degree of Ph.D. (Agricultural Economics) 


\title{
Elgilany A. Ahmed and Hamid Hussein M. Faki., 2020
}

Abdella AA (1995). The Agricultural Potential of Sudan. EIR Volume 28, Number 8, February 23, 2001.

River Nile State (RNS) Ministry of Agriculture: Report of Ministry of Agriculture in RNS season $2017 / 2018$.
River Nile State (RNS) Ministry of Agriculture: Report of Ministry of Agriculture in RNS season 2015/2016.

\section{الملخص العربي \\ الاثار الاقتصادية لتبنى تقنيات الري الحديثة بولاية نهر النيل في السودان دراسة حالة علف البرسيم البقولى}

\author{
الجيلاني عبدالحفيظ أحمد وحامد حسين محمد الفكي \\ مركز البحوث الاقتصادية والسياسات الزراعية ، هيئة البحوث الزراعية - السودان
}

التقنيات المتقدمة لديها القدرة على رفع كفاءة استخدام المياه وإنتاجية المياه لكل وحدة وكذلك الحال فى مورد العمالة. من الناحية الفنية،

فهي ذات صلة بالظروف التي تكون فيها المياه شحيحة وتكاليف الفرصة البديلة للعمالة مرتفعة. لقد حان الوقت لاختبار وتقييم التقنيات الحديثة

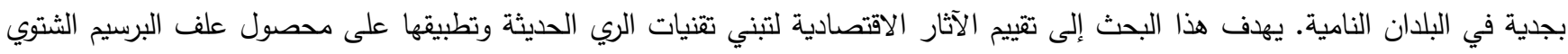
الموسمي بولاية نهر النيل فى شمال السودان. تم تطبيق تقنيات تحليلية متكاملة لتحقيق أهداف الدراسة. تحليل إحصائي وصفي لمياه المحاصيل

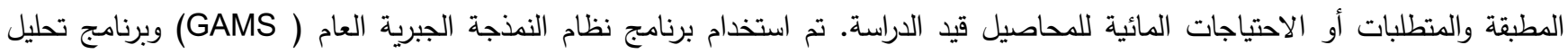
الحزمة الإحصائية للعلوم الاجتماعية (SPSS) وبرنامج تحليل الاحتياجات المائية (CropWat4) لتقييم أنظمة الزراعة الحديثة والتقليدية وأدائها

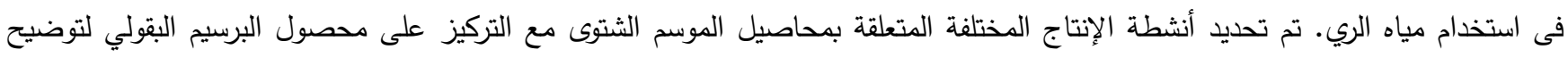

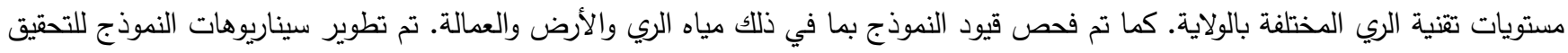

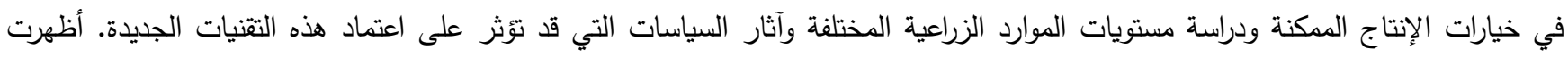

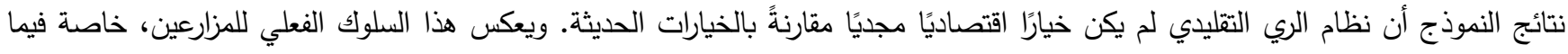

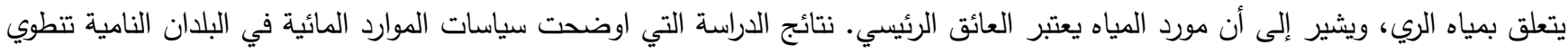

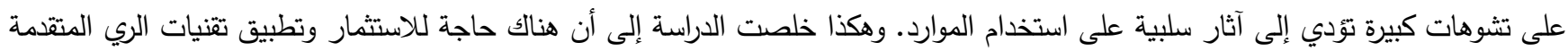
في مختلف القطاعات. الكلمات المفتاحية: التبني، تطبيق التكنولوجيا الحديثة ، علف البرسيم 